\title{
The Silence of Compliance: Child Soldier Trauma Narratives in Contemporary African War Novels
}

\author{
Vinod Kumar V \\ Department of English, Bharathidasan University, Tamilnadu, India \\ Gayathri S \\ Department of English, Bharathidasan University, Tamilnadu, India
}

\begin{abstract}
The victimhood of child soldiers is without any argument, a fact. In many wars, the illegitimate conscription of children under the age of eighteen has resulted in severe repercussions in the mental health of the child soldiers even after the war. Child soldier trauma depicted through many literary artifacts shows the intensity and gravity of the situation. The novels by Uzodinma Iweala, Chris Abani, and Chimamanda Ngozi Adichie viz Beasts of No Nation, Song for Night and Half of a Yellow Sun address the issue of child soldier conscription, the resultant trauma, and the slim chances of the betterment of the children even after the war is over. The paper moves toward acknowledging the victimhood of these children but at the same raising concerns about the agency of the trauma. The role of the child soldiers as perpetrators beyond their status of being victims and the necessity to provide proper psychosocio care to avert trauma and impending disorder in the society. A new approach concerning the grey area of in-betweenness in the victim/victimiser binary is needed while analysing desperate times like that of the Biafran civil war.
\end{abstract}

Index Terms - perpetrator trauma, victimhood, child soldiers, victim/victimiser, Nigerian civil war

\section{INTRODUCTION}

Trauma, a term which has gained popularity in psychoanalysis mainly during and after the world wars that shook even the foundation of world peace, has now become, for the lack of a more precise word, popular in usage and scope. The sociological and political aspects of trauma are most of the time underestimated with the universalisation of trauma as a psychologically disturbing event that focuses more on individuals and less on the community level. As the world has enormously disturbing episodes of so many atrocities, literature as a medium that reflects on multiple facets of society has never failed to capture their effects in literary artifacts. War narratives of contemporary African literature especially, have come out with many breath-taking efforts to delineate the trauma experienced by people during historically oppressed times - colonialism, racism, civil wars, discrimination at national and international levels etc. The atrocities and man-made horrors continue even during testing times questioning the very integrity of the core elements that make humanity. The remaining certainties of the uncertain world are chaos and the complex manifestations of the twisted psyche that turn out to be the residual remnants of greed.

Trauma narratives based on many events such as the Holocaust, World Wars I and II, the 9/11 attacks, the Vietnam war, etc are very popular and have achieved remarkable success in capturing the lost expressions in the shock of the events. However, experiences of the third world and postcolonial countries have drowned in a sea of neglect and lack of interest of the first world countries for a long time. It can be said that the articulation became more powerful and appeared more promising in its effect after the decline of colonialism. In the history of Africa especially, there has been umpteen number of man-made tragedies including racism, colonialism, civil wars, and the like. The Biafran civil war (1967-70) which wreaked havoc in Nigeria is an unforgettable experience for millions of population still now. The emerging number of books by Nigerian authors during contemporary times is a testimony to the still lasting impact of the war.

\section{TRAUMA NARRATIVES AND THE BIAFRAN WAR}

Uzodinma Iweala's Beasts of No Nation (2005), Chris Abani's Song for Night (2007), and Chimamanda Ngozi Adichie's Half of a Yellow Sun (2006) are notable and internationally acclaimed narrations on the Biafran civil war and its effects on a particular sect of people who have been tremendously affected by the war, the child soldiers. One of the most fascinating things about war narratives is the transgenerational power of trauma across generations and how the writers, even after many years of the war, still ponder over the subject of trauma related to the war when historical anecdotes interest the world with factual details alone. Renegotiating the traumatic experiences of the Biafran civil war makes the writers deal with the postcolonial angst of Nigeria. Studies related to war have often focussed deeply on the 
issue of child soldiers as the case is very sensitive and yet a continuing atrocity even during the present times. Recent writings regarding the issue by contemporary writers dwell mostly upon the psyche of the children who have been deprived of every childhood right. Under these circumstances, the characters showcased in the novel need to be studied under multiple glances because of not only the age and circumstances of the child soldiers but also the deeds of these children during direct or indirect combats.

While Beasts of No Nation follows closely the plight of young Agu, who had to join an army troop when his family got displaced and his father died, Song for Night trails on the journey of the character My Luck, who had been separated from his troop in a mine explosion. Both depict the tragic journey of children who are not even close to becoming adults but turned out to be soldiers. Half of a Yellow Sun however deals with the trauma of the civil population in general. It centers around how the Biafran civil war, in the course of its brutality, affects all the sections of society. The novel talks about a series of issues - women who get raped and murdered; men who get depressed and not being able to take care of families; children and adults who are forced into the army against their will and lose their lives; poverty, black market, and malnourishment among children; pathetic lives of people who tremble and try to escape to trenches upon air attacks, etc. It also brings in the issue of child soldier trauma along with other concerns.

The plot of Uzodinma Iweala's Beasts of No Nation centers around Agu and how he suffers at the hands of a loose army consisting of a paedophilic commander and crude soldiers. He gets raped and bullied to unimaginable levels and at the same time, the narrative informs what these kinds of situations can do to a child. Agu becomes one among them and enjoys killing after a while, finally being rescued to a comfortable place where he is properly taken care of. Though Chris Abani in Song for Night tells the tale of My Luck whose narrative is slightly better than the situation of Agu, the traumatic episodes are equally disturbing. My Luck's search for his army troop is the journey through his trials and tribulations throughout the war. His angst has an additional dark nature because of the suppressed voice. Though Half of a Yellow Sun is not limited to child soldier trauma like the other two novels, the experiences of Ugwu after being conscripted into the army are very important as it details the further character development and downfall of the character even after his rescue.

The main characteristic feature of the narratives is the way the writers have depicted the trauma of the child soldiers through unconventional manner. While Iweala undermines all the literary conventions of the language by making a small child his protagonist using broken languages and grammatically incorrect syntactical structures, Abani explores the voice behind the severed tongue of the character My Luck. Adichie also focuses on the life of Ugwu, a seemingly simple and expressive boy who suddenly became silent about his experience while in the army after being rescued. The prominent idea behind every child soldier narrative is typically presumed to feel sympathy towards the children who are forced against their will to do things and in the due process of war, go through a lot of personal traumas of their own, among men who have forgotten what essentially is humanity. How authorization was ever made to send these children to the frontline during a gruesome war instead of being protected irrespective of the tribe to which they belong, is a very much concerning social issue. Egodi Uchendu (2007) in the article titled "Recollections of Childhood Experiences during the Nigerian Civil War" revisits the experiences of earlier child soldiers and how they have been treated:

After exposure - often more than once - to the front line, some were sent home with post-traumatic stress syndrome, which during the Nigeria civil war was popularly called 'shell shock'. Some pretended to suffer from this condition in order to induce their demobilization. For the real victims of 'shell shock' in Biafra (but also in the Idoma and Tiv communities), it manifested in temporary deafness and displays of violent behaviour. (p. 403)

The concerned question here, though not usually asked because of the obvious age constraints and the exceptional situation of Nigerian civil war, is whether the child soldier trauma is owing to suffering or the unimaginable deeds they have done. It is quite an obvious fact that the grey area between victimhood and victimisation is somewhat inexplicable. Even then the silence and trauma of the child soldiers and the aspects behind that trauma cannot be presumed to be victimhood alone at all times. In the novels taken scrutiny, the authors, without giving any judgemental views, present the life of child soldiers as accurately as possible. Though tracking every character and their traumatic episode from a war narrative is difficult, there are certain aspects in the novels which put the audience in a conflict in determining the true nature of trauma.

\section{TRAUMATIC ViCTIMHOOD}

The character My Luck, in Song for Night, is the only character with an articulative voice throughout the novel and the rest of the characters occur only in the memories of My Luck. My Luck describes how the severed tongue affected the miners psychologically. When the army recruited the boys and Ijeoma, the only girl in the troop to be mine diffusers, the sheriff asked the doctor to cut off their tongues without their consent or giving any warning, in order to avoid the risk of them screaming in the battlefield and getting identified. Later, My Luck remembers how it only helped in increasing the volume of the screams they had in their heads. Abani (2007) talks about the underlying screams behind the silence of My Luck in the narrative. "What they couldn't know was that in the silence of our heads, the screams of those dying around us were louder than if they still had their voices" (p. 22). The unspeakable condition of trauma as advocated by the traditional trauma theorists such as Cathy Caruth is reflected in the muted voices of My Luck. Caruth (2016) in the book Unclaimed Experience: Trauma, Narrative, and History has elaborated on the concept of inability to 
express trauma as the major characteristic feature of any instance of traumatic experience. The incomplete accessibility to trauma causes the intensity:

The repetitions of the traumatic event which remain unavailable to consciousness but intrude repeatedly on sight thus suggest a larger relation to the event that extends beyond what can simply be seen or what can be known, and is inextricably tied up with the belatedness and incomprehensibility that remain at the heart of this repetitive seeing. (p. 92)

My Luck most of the time stays rational and acts according to the situation. He knows that being part of the platoon is the only way to survive and closely follows the training he has attended. However, he knows that behind the pretence of sanity, his mind is not at all in his control. My Luck periodically goes through everything that he has suffered. It is more apt to say that the remembrance of traumatic things is a part of his daily routine. However, one thing that is lacking is his awareness that he is indeed traumatized. He has exhibited all the classic symptoms of being traumatized hallucinations, panic attacks, restlessness, and lack of proper sleep along with his inability to utter a single sound. The psychological dimensions of My Luck's trauma are quite explicit throughout the novel.

In Beasts of No Nation too, Agu is faced with many traumatic episodes his psyche was not prepared for. To hit the reality, nothing can be done in preparing the mind to face a war, especially a war like that of the Nigerian civil war. Though the accurate age of the child soldiers cannot be determined from the narratives, the language structure from Agu as the protagonist gives a sense of his lesser age when compared to that of My luck and Ugwu. It is a misfortune that such a child at a young age has got the fate to see his known people die while trying to rescue their village. He became a part of that bloody war that has taken away all the dear and near ones in his life:

I am seeing man running with no headlike chicken, and I am seeing arm and leg everywhere. Then everything is just white and all I am hearing is step slap, step slap, step slap, and the sound of my own breathing. All of this is really happening to me? It is all happening like it is happening again and I cannot even be believing it. (Iweala 2005, p.89)

The effects of these instances on Agu's daily life are traumatic to such an extent that he somehow ends up becoming a different person thereafter. Agu has been forced to kill by the commandant:

He is grabbing my neck and whispering into my ear, kill him now because I am not having the time oh. If you are not killing him, enh. Luftenant will be thinking you are a spy. And who can know if he won't just be killing you. He is squeezing my hand around the handle of the machete and I am feeling the wood in my finger and in my palm. It is just like killing goat. Just bring this hand up and knock him well well. He is taking my hand and bringing it down so hard on top of the enemy's head and I am feeling like electricity is running through my whole body. The man is screaming, AYEEIII, louder than the sound of a bullet whistling and then he is bringing his hand to his head, but it is not helping because his head is spilling out like milk from coconut. (Iweala 2005, p.25)

From the moment of that murder onwards, everything for Agu has changed forever, even his perception of himself. The sad part about his experiences is that unlike others he does not know the source of the trauma he has been suffering. From the moment of witnessing his own father's gruesome murder, everything in his life has become so tragic that the marks left behind in his psyche got overlapped from time to time. Even Agu's last image of his father is not a pleasant one. "I am seeing all of the soldier with gun and knife and then I am thinking about my father just dancing like that because of bullet" (Iweala, 2005, p.13). "Nothing is the same anymore. I am not being able to be sleeping at all when it is time to sleep. Each time I am lying down my head, some voice inside of me is shouting and starting to make too much trouble so I cannot even be closing my eye" (Iweala, 2005, p.165). Iweala has successfully portrayed many of the characteristic features of trauma through the description of others characters in the novel. Griot, a small boy regularly has panic attacks and he sees frightening visions almost every night disrupting his peace of mind on an everyday basis. He has gone with his mother to the market to buy something because the family has been suffering from starvation. In an air attack by the enemy soldiers, he has witnessed the most atrocious deeds of war which caused innocent poor people to lose their lives in seconds when they least expected it.

I was just in the market when I am hearing GBWEM! I am just hearing one blast and the whole ground began to shaking shaking. And then those government pilot, they are just coming in low with their screaming plane and I was covering my ear but the drum were just beating TAKA TAKA TAKA and everybody is running this way and that way. This one is hiding under the wheelbarrow. That one is hiding in church. This one is jumping in gutter. I am not knowing where to be hiding so I am just running running up and down the road. I am hearing another GBWEM landing next right to me. And then I was feeling fire on my body but I wasn't burning. When I am looking up, I am seeing people hanging from tree like piece of meat. Head just hanging like coconut before it is falling off. (Iweala, 2005, p.97)

During the initial times of being forced to be a part of the army, Ugwu's condition was more or less the same as Agu and My Luck in the other novels. He could not confide in anyone how he has felt during the violence and murders. Though Ugwu did not understand the complete anarchy during wars, he is certain that if he wants to stay alive he has to obey the commander and follow the instructions. There are a lot of instances in the novel where Ugwu has chosen silence as his only method of coping with the unbearable time. From a character who used to talk a lot and ask a lot, he 
has become a silent being. It can be inferred that behavioural changes that occur due to traumatic situations have a lasting effect on the character of a person, especially among children:

There were more operations. Ugwu's fear sometimes overwhelmed him, froze him. He unwrapped his mind from his body; separated the two, while he lay in the trench, pressing himself into the mud, luxuriating in how close and connected he was to the mud. The $k a-k a-k a$ of shooting, the cries of men, the smell of death, the blasts of explosion above and around him were distant. But back at the camp his memory became clear; he remembered the man who placed both hands on his blown- open belly as though to hold his intestines in, the one who mumbles something about his son before he stiffened. And, after each operation, everything became new...He touched his own skin and thought of its decay. (Adichie, 2006, p.365)

Here, the fear insinuated in Ugwu's behaviour and general nature is quite understandable considering the circumstances and his situation. Like Agu, he has joined the army at a time he least expected it. When the three child soldier characters are considered, only My Luck has joined the army on his own. Even in My Luck's situation, he has joined the army because he wanted to save his life, since joining any side is the only viable option:

Nobody explained it at first. Nobody had time; nobody cared; after three years of civil war nothing is strange anymore; choose the reason that best satisfies you. There are many ways to say it, but this is the one I choose: they approached me and said I had been selected for a special mission. I had been selected to be part of an elite team, a team of engineers highly trained in locating and eliminating the threat of clandestine enemy explosives. Even though I had no idea what clandestine enemy explosives were, I was thrilled. (Abani, 2007, p.18)

Agu in the care and comfort of a family has been taken into the army as a child soldier when he was separated from his mother and sister, and his father got killed in action. Agu has been spotted by the soldiers of the opposite army who came soon after the ones who killed Agu's father and villagers left the scene. Though they first thought Agu is a spy used by the enemy soldiers and prepared to kill him after hitting him so many times, the Commandant has given him a chance to join the army. The intentions of the Commandant behind taking Agu with him, as revealed in the later sections of the novel, turned out to be purely paedophilic. But in the situation of not knowing the whereabouts of his mother and sister, and having witnessed his father being shot with multiple bullets, Agu has been left with no choice but to obey the Commander:

If you are staying with me, I will be taking care of you and we will be fighting the enemy that is taking your father. Are you hearing me? He is stopping and licking his lip. Are you hearing me? Everything will be just fine, he is saying with his lip so close to my ear that I am hearing his saliva in his mouth. I am looking and seeing his smile and feeling his hand on my face touching me softly...

What am I supposed to be doing?

So I am joining. Just like that. I am soldier (Iweala, 2005, p.13)

In Ugwu's case too, though not under the protection of his own family, Olanna and Odenigbo have offered him a sense of security and cared for him, and he was considered more a family member rather than a servant. And he has an experience where Olanna went of her ways and bribed the recruiters from taking Ugwu. Unfortunately for him, no one was there to help him this time, and against all his will he was conscripted into the army and he stayed with the army only because he was afraid that he might end up being shot if he tried to escape.

Ugwu began to run until he heard the gunshot, so deafening, so alarmingly close that he fell to the ground and waited for the pain to drill into his body, certain he had been hit. But there was no pain. When the soldier ran up to him, the first thing Ugwu saw was the pair of canvas shoes, before he looked up at the wiry body and scowling face. A rosary hung around his neck. The burnt smell of gunpowder came from his gun

'Come on, stand up, you bloody civilian! Join them there!'

Ugwu stood up and the soldier slapped the back of his head and a splintering light spread to his eyes; he dug his feet into the loose sand to steady himself for a moment before he walked over to join the two men standing with their arms raised high (Adichie, 2006, p.357)

In one way or the other, all the three main characters from three different novels, My Luck, Agu, and Ugwu are the victims of a brutal war they cannot escape. The horrible situations and the life-endangering day-to-day lives of the army people during desperate time are beyond imagination. These child soldiers have gone through the cruelties and miseries of war even when their psyche was splitting apart. Even when they want to come out of the army, they have no place to go. This applies to most of the child soldiers because most of them have witnessed either the terrible death of their family members or separation. Staying alive becomes the only option once they become child soldiers and there is no guarantee that they can become free one day even if the war comes to an end. For them, the trauma continues, and life itself becomes a traumatic episode.

Many instances can be cited to show how My Luck from Song for Night, has been affected by the traumatic instances he has witnessed. After seeing a group of old women eating the body of a small child, My Luck was not even able to rest for a long time. Abani (2007) in Song for Night explores the psyche of My Luck thoroughly. "It is that little face, maybe a few months old, that keeps me from the rest" (p.7). "I haven't rested since that night. There has been exhaustion; sleep even. But not rest" (p.16). "I couldn't eat it because it reminded me too much of the dead child in my dreams, and of that night we stumbled on that gory feast, those gorgons, and I felt the campsite as the others cooked and ate it (p. 41). Chris Abani has presented a series of instances where the character My Luck suffers. The journey to find 
his platoon becomes a journey through his trauma remembering the horrific images he has witnessed and experienced at various levels. The trauma and the psychological effect led to a silence that only aggravated the muteness of his voice.

\section{THE VICTIM-PERPETRATOR BINARY}

However, the conflict and dilemma in safely assuming the source of trauma emerge only when My Luck tries to analyse certain instances where he has gone wrong. My Luck is a person who has killed his own superior Major Essein to save a little girl from him. Though he has ended up killing both, his noble intention is unquestionable. Nevertheless, his motive behind some of the murders he has done is very much questionable. "I have killed many people during the last three years. Half of those were innocent, half of those were unarmed- and some of those killings have been a pleasure" (Abani,2007, p. 60). The pleasure part behind the killings is the fact that raises the question. It is a universally acknowledged matter that child soldiers were forced to do things they do not even like. My Luck has been forced to rape, to kill, to rob, etc. However, when he acknowledges the fact that he has relished some of the killings, he turns out to be a victimizer:

Who taught me to enjoy killing, a singular joy that is perhaps rivalled only by an orgasm? It doesn't matter how the death is dealt- a bullet tearing through a body, the juicy suck of a flesh around a bayonet, the grainy globular disintegration brought on by the clubs- the joy is the same and requires only the complete focus on the moment, on the act. (Abani, 2007, p.117)

In many studies related to trauma, the traumatic episodes of the victims assume primary importance. However, as the concept of the perpetrator is unavoidable, the narratives tangentially touch the issue. And some narratives focus on perpetrators and perpetrator trauma. The compartmentalisation, though essential as advocated by Dominick LaCapra in Writing History, Writing Trauma, child soldier trauma, is considered a grey area when the agency of the deed is considered. Though there is not much to argue about the victimhood of the child soldiers, the perpetrator tendency in them is a matter of dispute. Similar to My Luck in Song for Night, Agu in Beasts of No Nation has similarly expressed his obsession with being a perpetrator on his own accord. "Far away, I am hearing screaming and gunfire and my head is growing smaller and my body is growing bigger. I am wanting to kill; I don' know why. I am just wanting to kill. I am seeing animal and I am wanting to kill it" (Iweala, 2005, p.58).

Ugwu in Half of a Yellow Sun has always been affected by traumatic episodes after he raped an innocent bartender girl. He killed many people of the enemy camp during the war out of his helplessness as he was conscripted into the army. He has got the name Target Destroyer for his aim and execution of action. However, his own action against the girl whom he raped shows that there is a victimiser in him after all.

'No! Target Destroyer is next!'

Ugwu backed away from the door

'Ujo abiala o! Target Destroyer is afraid'

Ugwu shrugged and moved forwards. 'Who is afraid?' he said disdainfully.' I just like to eat before others, this is all.' (Adichie, 2006, p.365).

Here, Ugwu has chosen himself to be a victimiser. He is more conscious of his manly image before his group of army men. Though he has always been haunted by the image of the girl for the rest of his life, at that moment of action, he has chosen to do the act of rape at his own will. Though the situation of Ugwu is miserable, the deed he has done deserves no justification. It is cruel and one of the most atrocious forms of exerting his manhood. After his rescue, he has always been haunted by the hatred he saw in the eyes of the girl he raped. Later he cannot tolerate the grief when he came to know that his sister was raped by a group of soldiers. He has inflicted the pain on somebody and he pretty well knew that he has deserved the pain of knowing what his sister might have gone through.

Unlike Ugwu, My Luck, in Song for Night, does not want to rape anyone but he has to do it as per the instruction of his superior officer of the platoon:

"You are the only one who hasn't raped anyone yet!" he barked at me.

I wanted to ask him what this skirmish, this fight, this destruction of an innocent village had to do with our mission to defuse mines, but I knew better. I looked at the woman. My hesitation puzzled her and she stopped crying. John Wayne was angry at my insubordination and he pointed his gun at my head.

"Rape or die," he said, and I knew he meant it. (Abani, 2007, p.66)

In the case of My Luck, it is clear that he has to do it to save his life and nothing else. Though he has done many murders and violent activities, the rape of an innocent woman is never part of his own will. My Luck has a moral high ground compared to Ugwu when a similar situation is contrasted and evaluated. However, that does not save My Luck from the remorse he has after the act. It has taken Ijeoma a great deal to talk him out of guilt. Though My Luck is a victimiser, he is also a victim of the atrocities of war. The after-effects of all these actions had affected his mental stability and health.

Many other characters have chosen silence as their only mode of survival from exposing their traumatised psyche before the world. Strika, in Beasts of No Nation, another child soldier like Agu, has not said a single word but draws pictures of images that haunt him forever. LaCapra defines this repetitive behaviour of going through the traumatic event again and again as acting out. Strika's deal with repeatedly drawing pictures of horrible things, the way he was sexually molested by the Commander, and his vision of family as dead bodies hanging from trees are the examples of 
La Capra's concept of acting out. "This is very clear in the case of people who undergo a trauma. They have a tendency to relive the past, to be haunted by ghosts or even to exist in the present as if one were still fully in the past, with no distance from it" (LaCapra, 2014, p.143). In a case like that of Strika, the complete silence towards his own life and experiences may not turn out to be a temporary situation from which he can emerge unharmed when proper treatment is given. This is because the trauma of characters such as Strika is never properly addressed. Judith Lewis Herman (2015) in Trauma and Recovery opines that the silence of trauma victims is a grave condition:

All too commonly, chronically traumatized people suffer in silence; but if they complain at all, their complaints are not well understood. They may collect a virtual pharmacopeia of remedies: one for headaches, another for insomnia, another for anxiety, another for depression. None of these tends to work very well, since the underlying issues of trauma are not addressed (p. 86)

\section{SilENCE, SECRECY, AND COMPLIANCE}

In the case of Ugwu in Half of a Yellow Sun, the suffering is not known to anyone but himself. He has many chances to share it with others after his rescue but he has chosen not to do that. In his case, he is not afraid that his sufferings would not be understood by anybody, but at the same time his sufferings would also entail his horrendous deeds including murder and rape he committed during the war. This is quite applicable in the case of Agu in Beasts of no Nation and My Luck in Song for Night. In Beasts of No Nation, after his rescue, Agu has got the chance to share his experiences but he is not sure whether the listener, a white woman in charge of the home of rescued children of war, would relate to the things he says. He is always under the impression that the whole talking out process is doing nothing good as the listener is not an empathic one in his case. "But every time I am sitting with her I am like old man and she is like small girl because I am fighting in war and she is not even knowing what war is" (Iweala, 2005, p. 175). Even more than that, Agu has admitted that he cannot reveal everything to anyone even if he wanted. Even when he can tell certain things he has experienced during his conscription and his role as a child soldier during a brutal war, he cannot reveal any of the crimes he has done during the same situation. "I am saying to her sometimes, I am not saying many things because I am knowing too many terrible thing to be saying to you. I am seeing more terrible thing than ten thousand men and I am doing more terrible thing than twenty thousand men (Iweala, 2005, p.176).

When Agu has chosen to edit details of his experiences to the listener and Ugwu has chosen not to have a listener as he is too ashamed and afraid to reveal many things he has done, My Luck has spoken through the language of silence and that too with the people who have gone through the same ordeal as that of him. When the platoon aimed to kill a man, his wife sacrificed her own life by jumping in front of him and she was shot. My Luck and other members of the platoon have grieved for what they have done but all these kinds of instances prove that the child soldiers cannot reveal everything they have suffered in the war. If they have to come clean and out of their trauma, there is a necessity of honesty and it demands a lot of courage to be honest, especially in the case of the child soldiers:

We have seen fathers shoot their children on our orders, sons rape their mothers, children forced to hack their parents to death- the worst atrocities- all of which we witnessed impassively. But this was different. We all cried when the woman died, except John Wayne, who was well lost. It wasn't dramatic really, just silent tears and a shame that kept us from meeting each other's eyes. (Abani, 2007, p.83)

In this instance, it can be clearly stated that child soldiers are not just victims of the war or the atrocity of the system but they are the victimizers also. Though it is the circumstance of war that had turned them to become victimisers, the agency behind their actions cannot be ignored under any circumstances. Kali Tal (1995) in Worlds of Hurt: Reading the Literatures of Trauma opines those soldiers are at the same time both victims and victimizers. "Those exposed to combat or other life-threatening events, and those exposed to the carnage resulting from combat were traumatized...The soldier in combat is both victim and victimizer; dealing death as well as risking it" (Tal, 1995, p. 10).

Though the trauma of the victims is though seen in a humanitarian light, not all the traumatic experiences of the child soldiers could be considered so. Notably, the novels touch many instances where the characters ruminate on the events which led them to kill innocent people out of their frustration or sometimes to their enjoyment. It is quite accurate to describe the dual role of child soldiers as victims/perpetrators. Hence child soldiers cannot be considered in the limelight of glorious victims alone. The trauma narratives delineate the instances where war situations make child soldiers partly monsters. These instances prove that the grey zone of compliance, at times, can make the child soldiers perpetrators. The factor that they are under aged does not give any justification to the compliance to horrible deeds they have done.

In many studies, it has been proven that these young children with such exposure may turn out to be more dangerous to civil life in their adulthood. "Trauma appears to amplify the common gender stereotypes: men with histories of childhood abuse are more likely to take out their aggressions on others, while women are more likely to be victimized by others or to injure themselves" (Herman, 2015, p.82). None of the novels touch on the future of the child soldiers. Towards the end of the narratives, except for My Luck, the child soldiers seemed to get rescued from the war and their life of being child soldiers. Though the future endeavours are not explicitly mentioned, the writers have hinted at the disturbed psyche of the characters who never let go of the past experiences and the trauma associated with them. (Reading along the lines of Herman's theory shows that such character types may continue their life in the same way, further resulting in a potential threat to themselves and the society too in future. 
Arguments like that of the mental stability of these ill-fated children conscripted into the army can counter the theory of compliance of child soldiers but the enjoyment part as claimed by them while doing a murder cannot be disregarded as negligible. One such occasion is in which Agu confuses a mother and a daughter to be his own family under special circumstances. However, the moment he realised the truth, he willingly took part in cutting the arms of the daughter and raping the mother. Trauma arises out of being forced to do something atrocious and the trauma that comes out later from willingly taking part in a monstrous deed cannot be considered equally. The silence of trauma as depicted through certain characterisation in the novels is not only pointed solely at victimhood but also at compliance to crime and gruesome murders at own will. A typical attempt of the perpetrator's mind to justify what they have done even after knowing that there is no logic behind is exhibited by Agu in Beasts of No Nation. After the murders, he keeps calming himself and tries to come out of hallucinations and panic attacks:

I am not bad boy. I am not bad boy. I am soldier and soldier is not bad if he is killing. I am telling this to myself because soldier is supposed to be killing, killing, killing...I am singing song to myself because I am hearing too many voice in my head telling me I am a bad boy. They are coming from all around me and buzzing in my ear like mosquito and each time I am hearing them, they are chocking my heart and making my stomach to turn. So I am singing

Soldier Soldier

Kill Kill Kill

That is how you live.

That is how you die (Iweala,2005, p.30)

Judith Herman (2015) in Trauma and Recovery, details the psyche behind the silence and secrecy of the perpetrators regarding the deeds they have done.

In order to escape accountability for his crimes, the perpetrator does everything in his power to promote forgetting. Secrecy and silence are the perpetrator's first line of defense. If secrecy fails, the perpetrator attacks the credibility of his victim... To this end, he marshals an impressive array of arguments, from the most blatant denial to the most sophisticated and elegant rationalization (Herman, 2015, p. 4)

In this context, for My Luck in Song for Night, the silence though is enforced and traumatic, it is his way of escaping from owning up the agency of his trauma. Similarly, Strika, the character in Beasts of no Nation, is suffering a lot from angst and his silence is the proof that trauma can steal the articulative power of a person, especially a child. However, the agency behind that trauma is not clear from the narrative. Strika has been sexually abused by the commander. The pictures he draws when asked about his family, clearly show that he has witnessed their tragic end. But the acts of violence he has done while he is in the army and his compliance to many murders and rape cannot be ignored in this situation. My Luck in Song for Night has carved his hands multiple times in remembrance of the people he has killed. In the chapter "Memory is a Pattern Cut into an Arm" (Abani 23), he talks about the crosses he has carved on his hands for friends and relatives and the two strangers. For a person who has kept a tab for the traumatic accounts of loved ones, it is a bit strange if his total neglect of the people he has killed with enjoyment seems unintentional. Ugwu in Half of a Yellow Sun chooses the option to write a book with the title The world Was Silent when We Died. He has covered many aspects right from the start of the war and included the pathetic life of the civilians. He articulated how no one helped the poor people who tried in vain to escape death and starvation. Yet, he stayed silent throughout about his experiences while he was in the army intentionally hiding his sufferings as well as his actions. The silence in most cases appears to be intentional. The child soldiers during the course of time have lost their child-like nature owing to war. Though some have taken up responsibility of actions, many have not done that. It is clear that silence of the child soldiers is not always a sign of victimhood. At many instances, the silence is the indication of grief, shame, and sometimes secrecy. Suppressing the agency behind the trauma is equally traumatic in intensity as that of victimhood. However, the compartmentalisation cannot be accurately done as child soldiers are both victims and victimisers.

\section{CONCLUSION}

The narratives of Uzodinma Iweala and Chris Abani and Chimamanda Ngozi Adichie show the angst of child soldiers who happened to be the prey of a desperate time in the history of Nigeria - the Nigerian Civil war. The novels capture every aspect of child soldier trauma - from the clinical symptoms to the complicated expressions. Though the agency behind traumatic instances is never fully recognized due to obvious reasons, especially in the case of child soldiers, the chance of perpetrator trauma cannot be ruled out. These trauma narratives open up avenues of opportunities for discussing the agency behind child soldier trauma. The secrecy and silence of the compliance are explicit. Finding a cure for trauma, without proper articulation and expression, is almost next to impossible. Though the perpetrator trauma is often seen in a different light, the betterment lies in treating the characters considering being victims, but still understanding the potential for danger as there are elements of victimisers in them. If one is indeed in search of the true victimizer, the quest should go beyond just the child soldiers and who made them victimisers in the first place.

\section{REFERENCES}

[1] Abani, C. (2016). Song for night. Telegram. 
[2] Adichie, C. N. (2007). Half of a Yellow Sun. Anchor.

[3] Caruth, C. (2016). Unclaimed Experience: Trauma, Narrative and History (20th ed.). Johns Hopkins University Press.

[4] Herman, J. L. (2015). Trauma and Recovery: The Aftermath of Violence--From Domestic Abuse to Political Terror (1R ed.). Basic Books.

[5] Iweala, U. (2006). Beasts of No Nation (Reprint ed.). Harper Perennial.

[6] LaCapra, D. (2014). Writing History, Writing Trauma (Parallax: Re-visions of Culture and Society) (Reprint ed.). Johns Hopkins University Press.

[7] Tal, K. (1995). Worlds of Hurt: Reading the Literatures of Trauma (Cambridge Studies in American Literature and Culture, Series Number 95). Cambridge University Press

[8] Uchendu, E. (2007). Recollections of Childhood Experiences During the Nigerian Civil War. Africa, 77(3), $393-418$. https://doi.org/10.3366/afr.2007.0063

Vinod Kumar V is a Professor of English at Bharathidasan University, Tiruchirappalli, Tamilnadu, India. After obtaining M.A. and M.Phil. in English and Comparative Literature from Madurai Kamaraj University, he completed his Ph.D. in English Language Teaching at Gandhigram Rural Institute (Deemed University). Additionally, he holds an M.A. Degree in Mass Communication and Journalism. With more than two decades of teaching and research experience, he has successfully guided eight Ph.D. and more than fifty M.Phil. researchers, so far. He has published thirty-two research articles in journals of repute and has edited two books. He has delivered more than fifty invited lectures on different occasions in different capacities. At present, he is the Director of Internal Quality Assurance Cell (IQAC) of the University. Formerly, he held various administrative responsibilities including the Dean of Languages, Head of the Department of English, Director of Centre for Distance Education. He was awarded Associateship at Indian Institute of Advanced Studies (IIAS), Shimla for a period of 3 years from 2014 to 2016.

Gayathri $\mathbf{S}$ is a Ph.D. scholar in the Department of English, Bharathidasan University, Tiruchirappalli, Tamilnadu, India. She completed her MA from St. Thomas college, affiliated to Mahatma Gandhi University, Kerala and obtained M.Phil. from Bharathidasan University. She has to her credit several paper presentations in National and International conferences. She is currently focussing on research pertaining to Postcolonial Nigerian literature and Trauma Studies. 